\title{
Effect of lead and nickel toxicity on chlorophyll and proline content of Urd (Vigna mungo L.) seedlings
}

\author{
Gurpreet Singh, Rajneesh K. Agnihotri, Rajendra Sharma Reshma and Mushtaq Ahmad
}

Department of Botany, School of Life Sciences, Dr. B. R. Ambedkar University, Khandari Campus, Agra - 282002, India.

Accepted 13 June, 2012

\begin{abstract}
The effect of $\mathrm{Pb}$ and $\mathrm{Ni}$ on chlorophyll $\mathrm{a}, \mathrm{b}$, carotenoids and proline content of Black gram (Vigna mungo L.) seedlings were evaluated under 10, 50 and $100 \mu \mathrm{M}$ concentration. These concentrations significantly affected chlorophyll, carotenoid and proline content of Black gram as compared to control. $\mathrm{Pb}$ and $\mathrm{Ni}$ at $10 \mu \mathrm{M}$ concentration resulted in less significant effect on chlorophyll, $\mathrm{a}, \mathrm{b}$ and carotenoids. Carotenoids were less affected compared to $\mathrm{Chl}$ a and $\mathrm{b}$, while higher concentrations (50 and $100 \mu \mathrm{M}$ ) significantly reduced chlorophyll and carotenoid contents of the seedlings. However, the addition of nitrogen $(5 \mathrm{mM})$ somehow minimized the effect of these heavy metals. Nitrogen increased the chlorophyll content of metal treated plants. The proline content of plants was increased under $\mathrm{Pb}$ and $\mathrm{Ni}$ treatments $(10,50$ and $100 \mu \mathrm{M})$. In this case, the additional supply of nitrogen in the form of ammonium nitrate decreased proline content of plants treated with $\mathrm{Pb}$ and $\mathrm{Ni}$.
\end{abstract}

Key words: Carotenoid, chlorophyll, lead, nickel, proline, Vigna mungo.

\section{INTRODUCTION}

Black gram (Vigna mungo L.) is a member of family Fabaceae. It is an annual and important short duration pulse crop growing in many parts of India and cultivated both in kharif and rabi season. It is native to Central and South East Asia. The optimum temperature for better growth of black gram ranges between 25 to $35^{\circ} \mathrm{C}$, but it can tolerate upto $42^{\circ} \mathrm{C}$ which permit to cultivate during summer and winter seasons. Black gram is cultivated both in hilly and plain regions and commonly grown upto $1800 \mathrm{~m}$ amsl with short duration (90-120) and high nutritive value (El-Karamany, 2006).

It is quite drought resistant but intolerant of frost and prolonged cloudiness. Black gram is sown in most of the soils but it can grow better on heavier soils ( $\mathrm{pH} 5.5$ - 7.5) with an annual rainfall of $600-1000 \mathrm{~mm}$ (Chauhan et al., 2010). Amongst many abiotic stresses, heavy metal toxicity is very important, especially of crop species that are grown in the vicinity of sites of heavy industry, particularly in developing countries (Bi et al., 2006; Ona et al., 2006).

The toxicity of heavy metals is a problem for ecological,

*Corresponding author. E-mail: rk_agnihotri@rediffmail.com. Tel: 09412045450. evolutionary and environmental reasons (Nagajyoti et al., 2008). $\mathrm{Pb}$ tends to accumulate in the ground surface layer and its concentration decreases with soil depth (De Abreu et al., 1998). Pb is considered as a general protoplasmic poison which is cumulative slow acting and subtle. Soil contaminated with $\mathrm{Pb}$ cause sharp decrease in crop productivity thereby posing a serious problem for agriculture (Johnson and Eaton, 1980). Maximum Pb content is found in senescing leaves and least in young leaves (Godzik, 1993). Pb moves predominantly into the root apoplast and thereby in a redial manner across the cortex and accumulates near the endodermis. The endodermis acts as a partial barrier to the movement of $\mathrm{Pb}$ between the root and the shoot (Jones et al., 1973; Verma and Dubey, 2003). Pb decreases germination percentage of plant, root/shoot length, tolerance index and dry mass of roots and shoots (Mishra and Chaudhary, 1998). The key enzyme for chlorophyll biosynthesis that is, $\alpha$-amino laevulinate dehydrogenase is strongly inhibited by $\mathrm{Pb}$ ions (Prasad and Prasad, 1987).

Nickel, one of the important heavy metal pollutants is of considerable concern because its concentration is rapidly increasing in soils of different parts of the world (Echevarria et al., 1998; Faryal et al., 2007; Atiq-urRehman and lqbal, 2008). The increasing concentration of $\mathrm{Ni}^{2+}$ has been shown to inhibit seed germination and 
Table 1. Effect of Lead and Nickel on chlorophyll, carotenoids and proline content in Black gram (V. mungo L.) grown with or without nitrogen (N).

\begin{tabular}{|c|c|c|c|c|c|c|c|c|c|c|c|}
\hline \multirow{2}{*}{$\begin{array}{l}\text { Metals } \\
\text { Control } \\
\end{array}$} & \multirow{2}{*}{$\begin{array}{c}\text { Concentration } \\
(\mu \mathrm{M})\end{array}$} & \multicolumn{2}{|c|}{ Chlorophyll a } & \multicolumn{2}{|c|}{ Chlorophyll b } & \multicolumn{2}{|c|}{ Total Chlorophyll } & \multicolumn{2}{|c|}{ Carotenoids } & \multicolumn{2}{|c|}{ Proline } \\
\hline & & $0 \mathrm{mM} \mathrm{N}$ & $5 \mathrm{mM} \mathrm{N}$ & $0 \mathrm{mM} \mathrm{N}$ & $5 \mathrm{mM} \mathrm{N}$ & $0 \mathrm{mM} \mathrm{N}$ & $5 \mathrm{mM} \mathrm{N}$ & $0 \mathrm{mM} \mathrm{N}$ & $5 \mathrm{mM} \mathrm{N}$ & $0 \mathrm{mM} \mathrm{N}$ & $5 \mathrm{mM} \mathrm{N}$ \\
\hline \multirow[t]{2}{*}{ Control } & 0 & $0.176 \pm 0.003$ & $0.298 \pm 0.002$ & $0.309 \pm 0.001$ & $0.419 \pm 0.015$ & $0.485 \pm 0.004$ & $0.717 \pm 0.001$ & $0.524 \pm 0.001$ & $0.639 \pm 0.015$ & $0.029 \pm 0.002$ & $0.015 \pm 0.001$ \\
\hline & 10 & $0.166 \pm 0.001$ & $0.224 \pm 0.002$ & $0.252 \pm 0.015$ & $0.380 \pm 0.015$ & $0.418 \pm 0.003$ & $0.604 \pm 0.002$ & $0.466 \pm 0.015$ & $0.516 \pm 0.003$ & $0.032 \pm 0.003$ & $0.020 \pm 0.001$ \\
\hline \multirow[t]{3}{*}{$\mathrm{Pb}$} & 50 & $0.150 \pm 0.002$ & $0.209 \pm 0.004$ & $0.230 \pm 0.015$ & $0.362 \pm 0.015$ & $0.380 \pm 0.003$ & $0.571 \pm 0.002$ & $0.441 \pm 0.001$ & $0.481 \pm 0.002$ & $0.034 \pm 0.001$ & $0.022 \pm 0.002$ \\
\hline & 100 & $0.147 \pm 0.002$ & $0.197 \pm 0.002$ & $0.204 \pm 0.001$ & $0.324 \pm 0.015$ & $0.351 \pm 0.001$ & $0.521 \pm 0.001$ & $0.420 \pm 0.015$ & $0.460 \pm 0.003$ & $0.038 \pm 0.002$ & $0.023 \pm 0.015$ \\
\hline & 10 & $0.140 \pm 0.003$ & $0.180 \pm 0.003$ & $0.202 \pm 0.002$ & $0.310 \pm 0.015$ & $0.342 \pm 0.002$ & $0.490 \pm 0.005$ & $0.409 \pm 0.001$ & $0.469 \pm 0.002$ & $0.040 \pm 0.001$ & $0.025 \pm 0.001$ \\
\hline \multirow[t]{2}{*}{$\mathrm{Ni}$} & 50 & $0.064 \pm 0.002$ & $0.123 \pm 0.002$ & $0.085 \pm 0.001$ & $0.315 \pm 0.002$ & $0.149 \pm 0.004$ & $0.258 \pm 0.003$ & $0.272 \pm 0.015$ & $0.312 \pm 0.001$ & $0.042 \pm 0.015$ & $0.027 \pm 0.015$ \\
\hline & 100 & $0.057 \pm 0.002$ & $0.117 \pm 0.002$ & $0.068 \pm 0.015$ & $0.123 \pm 0.015$ & $0.125 \pm 0.002$ & $0.240 \pm 0.003$ & $0.245 \pm 0.001$ & $0.280 \pm 0.002$ & $0.049 \pm 0.015$ & $0.029 \pm 0.001$ \\
\hline
\end{tabular}

$\mathrm{N}$ - Nitrogen, Mean \pm - Standard Error.

seedling growth of different plant species (Espen et al., 1997; Faroogi et al., 2009). Nickel stimulates many enzymatic activities at very low concentration and it found a part of active metallo center of hexamer enzyme urease (Gerendas et al., 1999). Nickel is rapidly taken up by the plant root system and research with different plant species have shown that $\mathrm{Ni}$ is able to inhibit a large number of plant enzymes such as those of Calvin cycle and chlorophyll biosynthesis (Van Assche and Clijsters, 1990).

Proline is an amino acid which could play a therapeutic role in plants (Singh et al., 1973; Flower et al., 1977). Proline, sugar, glycine, betaine and other organic solutes are believed to improve metal tolerance by contributing to osmosis and preserving enzyme activity in presence of toxic ions (Greenway and Munns, 1980).

It has been shown that nitrogen has significant effect on crop plants under stress conditions. Nitrogen induced the pigment composition and leaf area in various crops when provided exogenously. The availability of nitrogen fixation sensitivity to drought has been analyzed with several grain legumes including $V$. mungo $\mathrm{L}$.
(Sinclain and Seeraj, 1995). Keeping all these effects in mind the present investigation was executed with an objective to study the role of lead and nickel on cholrophyll, carotenoid and proline content of Vigna mungo at different concentrations.

\section{MATERIALS AND METHODS}

The seeds of $V$. mungo L. Hepper var. Shekhar 3 (KU 309) were obtained from Agricultural Seed Company, Belanganj, Agra. The seeds were surface sterilized with $0.1 \%$ of sodium hypochlorite to prevent any fungal contamination. Then after washing with distilled water and were then soaked in $5 \%$ bavistin (a systemic fungicide) for $15 \mathrm{~min}$. The sand was thoroughly washed with sodium hypochlorite and dried. The seeds were sown in earthen pots containing 4:1 soil and farm yard manure. The soil was treated with Long Ashton nutrient solution (Hewitt, 1966). Metal treatments of $\mathrm{Pb}$ and $\mathrm{Ni}$ were prepared using lead nitrate and nickel chloride solutions (10,50 and 100 $\mu \mathrm{mol} / \mathrm{L}$ ). Nitrogen was prepared using ammonium nitrate at $5 \mathrm{mM} / \mathrm{L}$ concentration. $\mathrm{Pb}$ and $\mathrm{Ni}$ (control, 10,50 and 100 $\mu \mathrm{M})$ were provided along with nutrient solution twice a week. Nitrogen was also provided along with nutrient solution. Three identical sets were maintained during the whole experiment and the experiments were conducted in green house to provide control conditions. The samples were taken from three week old seedlings for biochemical analysis. The chlorophylls and carotenoids were estimated by Arnon's (1949) technique using double beam UV-visible spectrophotometer (systronics). The proline was estimated by using Bates et al. (1973) method.

\section{RESULTS AND DISCUSSION}

\section{Effect of heavy metals on chlorophyll and carotenoids}

Data presented in Table 1 shows that the effect of $\mathrm{Pb}$ and $\mathrm{Ni}(10,50$ and $100 \mu \mathrm{M} / \mathrm{L})$ and their interaction with nitrogen $(5 \mathrm{mM} / \mathrm{L})$ on chlorophyll and carotenoids content of black gram plants. $\mathrm{Pb}$ and $\mathrm{Ni}$ at $10 \mu \mathrm{M}$ reduced chlorophyll a to 0.1666 and $0.140 \mathrm{mg} \mathrm{g}^{-1} \mathrm{Fw}$ respectively in comparison to control. Chlorophyll b at $10 \mu \mathrm{M}$ reduced upto 0.252 and $0.202 \mathrm{mg} \mathrm{g}^{-1} \mathrm{Fw}$ compared to control (0.309 $\left.\mathrm{mg} \mathrm{g}^{-1} \mathrm{Fw}\right)$, while chlorophyll a at $50 \mu \mathrm{M} / \mathrm{L}$ concentration reduced upto 15 and $64 \%$ but chlorophyll b reduced upto 26 and $72 \%$ as compared to control at $50 \mu \mathrm{M} / \mathrm{L}$ concentration (Figure 1a). The chlorophyll a reduced 16 and 

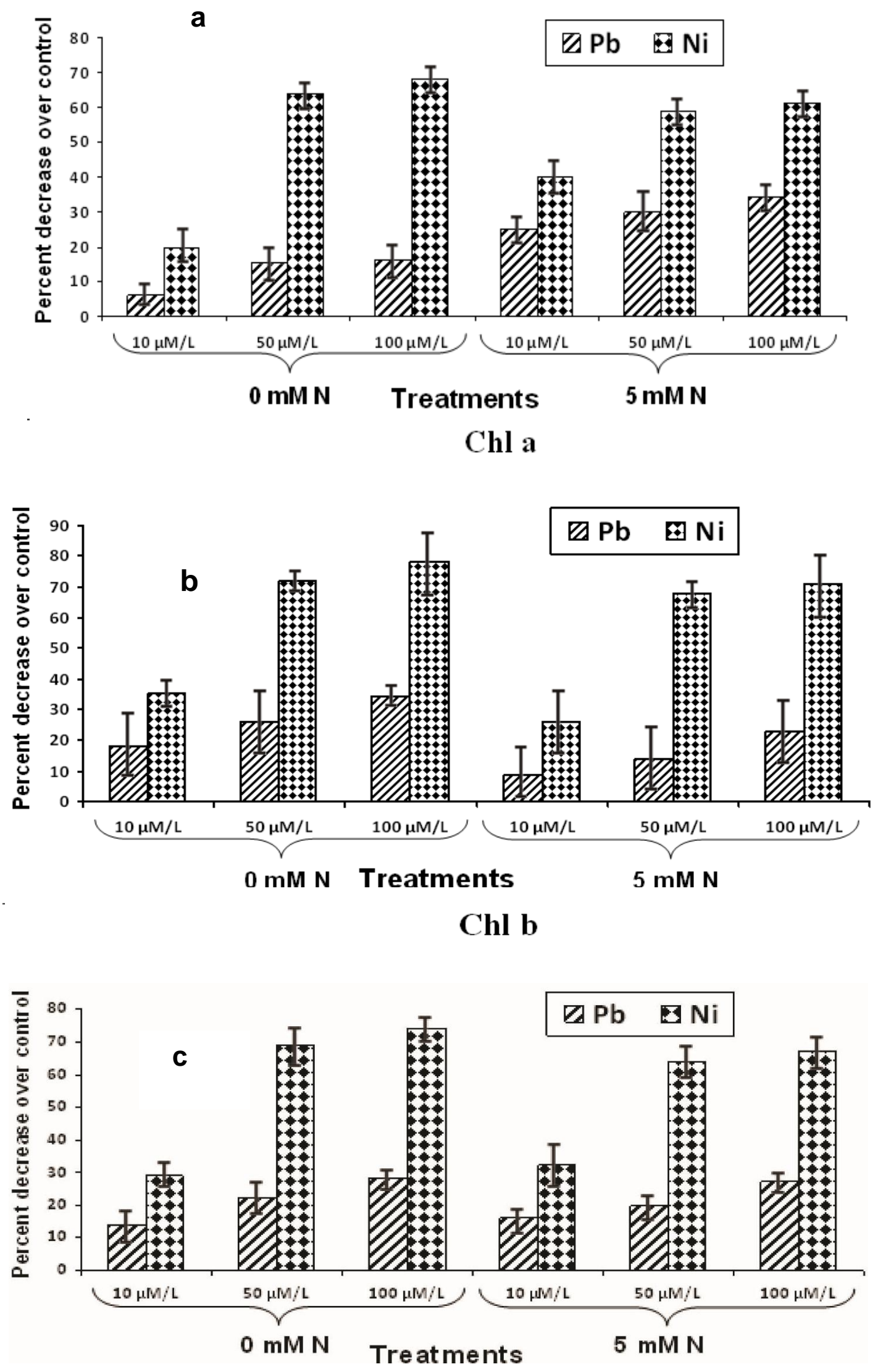

Figure 1. Total chlorophyll. 


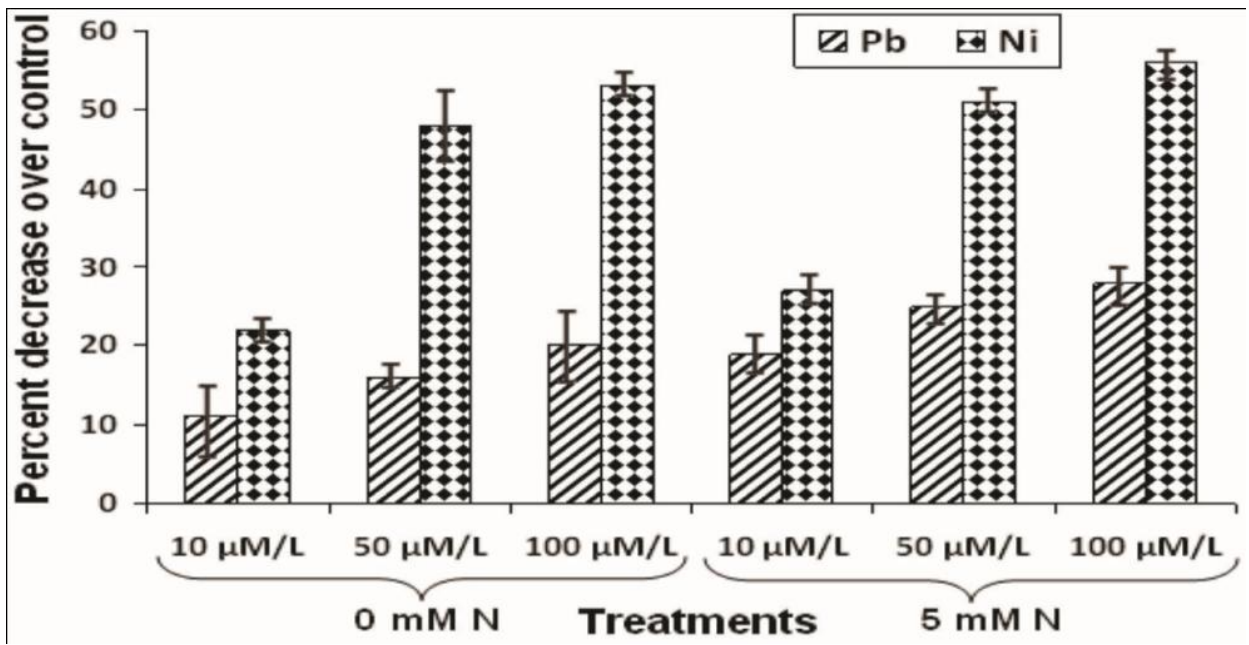

Figure 2. Carotenoids.

$68 \%$ by $\mathrm{Pb}$ and $\mathrm{Ni}$ at $100 \mu \mathrm{M}$ concentration compared to control. A corresponding result in chlorophyll b were 34 and $78 \%$ (Figure 1b). Total chlorophyll was reduced upto 16 and $32 \%$ at $10 \mu \mathrm{M} / \mathrm{L}$ concentration. At $50 \mu \mathrm{M} / \mathrm{L}$ concentration total chlorophyll was reduced upto 20 and $64 \%$. But at higher concentration $(100 \mu \mathrm{M} / \mathrm{L})$, the reduction was 27 and $67 \%$ as compared to control (Figure 1c). On the contrary, additional supply of nitrogen (Ammonium nitrate) $5 \mathrm{mM} / \mathrm{L}$ in nutrient medium somehow minimized the effect of heavy metals and proved beneficial for all pigments studied (Figure 1a, b, c).

An examination of Figure 2 reveals that plants under control without nitrogen exhibited $0.524 \mathrm{mg} \mathrm{g}^{-1} \mathrm{Fw}$ and with nitrogen $0.639 \mathrm{mg} \mathrm{g}^{-1} \mathrm{Fw}$ of carotenoid content. However, when the $\mathrm{Pb}$ and $\mathrm{Ni}$ at $10 \mu \mathrm{M}$ without nitrogen were supplied the decrease in carotenoid content was 11 and $22 \%$, respectively. When the nitrogen was applied the increase was found to be 19 and $27 \%$ over control. Similarly at higher concentration of both these metals the decrease in carotenoid content was found to be 20 and $53 \%$, however, when nitrogen was applied the increase in carotenoid content was found to be 28 and $56 \%$. This is in accordance with the results reported by Panda and Khan (2003) who found carotenoid content decreased in rice under heavy metals.

Similar results have been obtained by several workers working on various crops. The study on $V$. mungo leaves suggested that decline in Chl. content in shoots of metal treated plants resulted mostly from its enhanced degradation or reduced synthesis (Stobart et al., 1985; Somashekaraiah et al., 1992). Nagajyoti et al. (2008) reported the reduction in Chlorophyll a, Chl. b and total chlorophyll in groundnut by industrial effluents containing heavy metals. Chlorophyll content decreased in leaves exposed to $\mathrm{Cd}$ stress were also reported in $V$. mungo (Singh et al., 2008). Reduced chlorophyll content due to nickel toxicity in different plant species has been well documented (Pandey and Pathak, 2006).

\section{Effect of heavy metals on proline}

The effect of $\mathrm{Pb}$ and $\mathrm{Ni}$ on proline content of Black gram and their interaction with nitrogen is shown in Figure 3. Plants grown with $\mathrm{Pb}$ and $\mathrm{Ni}$ showed rapid accumulation of proline. As compared to control $(0.029) \mathrm{mg} \mathrm{g}^{-1}$ proline, plants showed an increase upto 0.032 and $0.040 \mathrm{mg} \mathrm{g}^{-1}$ proline under $\mathrm{Pb}$ and $\mathrm{Ni}$ treatments at $10 \mu \mathrm{mol} / \mathrm{L}$ concentrations. At $(50 \mu \mathrm{mol} / \mathrm{L})$ concentration, proline content was enhanced upto 15 and $31 \%$ under $\mathrm{Pb}$ and $\mathrm{Ni}$ treatments over control. However at higher concentration $(100 \mu \mathrm{mol} / \mathrm{L})$ proline content was further enhanced up to 31 and $69 \%$ over control under $\mathrm{Pb}$ and $\mathrm{Ni}$ treatments. In this case, nitrogen application reduced the proline content in $V$. mungo L. plants.

At higher concentration $(100 \mu \mathrm{mol} / \mathrm{L})$, proline content was reduced upto 55 and $93 \%$ over control under $\mathrm{Pb}$ and $\mathrm{Ni}$ treatment. Our results are in agreement with several workers worked on several crops (Singh et al., 1973; Flower et al., 1977; Chris et al., 2006; John et al., 2009). Proline, an osmoprotectant, accumulate under heavy metal stress, and give rise to a series of reactions, which generate numerous free radicals by altered levels of major anions and accumulation (Alia and Saradhi, 1991). Proline is supposed to participate in the reconstruction of chlorophyll, activate the Krebs cycle and also in the energy source (Saxe, 1991).

\section{Conclusion}

Based on the results it can be concluded that chlorophyll, carotenoid, and proline contents were seriously affected by heavy metals (both these). Chlorophyll a was affected 


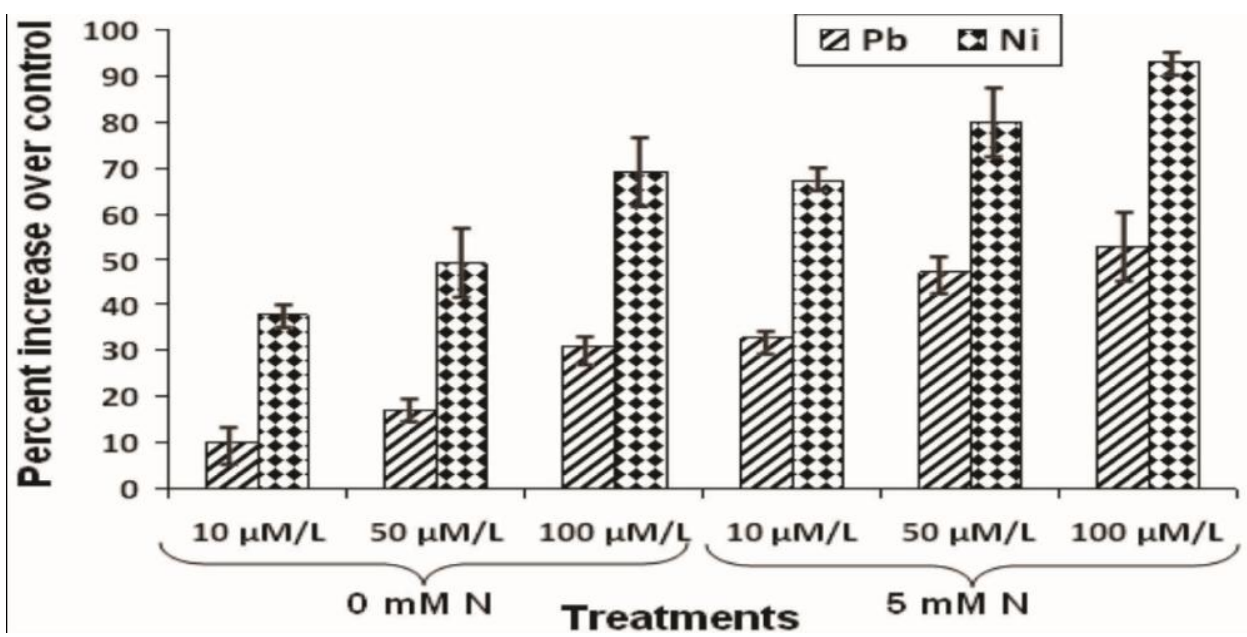

Figure 3. Proline content.

more as compared to chlorophyll $b$ whereas carotenoids were less affected then $\mathrm{Chl} a$ and $b$. The amount of proline increased in plants under stress caused by these heavy metals. Nickel proved to be more toxic than lead at all the three concentrations $(10,50$ and $100 \mu \mathrm{M})$. The deleterious effects of heavy metals may be alleviated in plants if provided with appropriate concentration and form of nitrogen in nutrient medium. Further more research is needed in order to evaluate the effect of different heavy metals on various crops especially in the Braj (Agra and Mathura) region.

\section{REFERENCES}

Alia P, Saradhi P (1991). Proline accumulation under heavy metal stress. J. Plant Physiol. 138:554-558.

Arnon DI (1949). Copper enzyme in isolated chloroplasts, polyphenol oxidase in Beta vulgaris. Plant Physiol. 24:1-15.

Atiq-ur-Rehman S, Iqbal MZ (2008). Level of heavy metals in the foliage of naturally growing plants collected from Korangi and Landhi areas of Karachi city, Pakistan. Pak. J. Bot. 40:785-789.

Bates LS, Waldren RP, Teare ID (1973). Rapid determination of free proline for water stress studies. Plant Soil 39:205-207.

Bi X, Feng X, Yang Y, Qui G, Li G, Li F, Li UT, Fu Z, Jin Z (2006). Environmental contamination of heavy metals from zinc remelting areas in Hezhang country, Western Guizhox, China. Environ. Intern. 32:883-890.

Chauhan JS, Tomar YK, Anoop BN, Indra KS, Seema A, Debarati A (2010). Morphology, germination and early seedling growth. J. Am. Sci. 6(1):34-41.

Chris A, Zeeshan M, Abraham G, Prasad SM (2006). Proline accumulation in Cylindrospermum sp. Environ. Exp. Bot. 57:154-159.

De Abreu CA, de Abreu MF, deAndrade JC (1998). Distribution of lead in the soil profile evaluated by DTPA and Mehlich - 3 solutions. Bragantia 57:18-192.

Echevarria G, Morel JL, Fardeau JC, Lecler c-cessac E (1998). Assessment of phytoavailability of nickel in soils. J. Environ. Qual. 27:1064-1070.

El-Karamany MF (2006). Double purpose (Forage and seed) of mung bean production 1-effect of plant density and forage cutting date on forage and seed yields of mungbean (Vigna radiata (L.) Wilczck). Res. J. Agric. Biol. Sci. 2:162-165.

Espen L, Pirovano L, Sergio MC (1997). Effect of nickel during the early phases of radish (Raphanus sativus) seed germination. Environ. Exp. Bot. 38:187-197.

Farooqi ZR, Zafar lqbal M, Kabir M, Shafiq M (2009). Toxic effects of lead and cadmium on germination and seedling growth of Albizia lebbeck (L) Benth. Pak. J. Bot. 41:2-33.

Faryal R, Tahir F, Hameed A (2007). Effect of waste water irrigation on soil along with its micro and macro flora. Pak. J. Bot. 39:193-204.

Flowers TJ, Troke PF, Yeo AR (1977). The mechanisms of salt tolerance in halophytes. Ann. Rev. Plant Physiol. 28:89-121.

Gerendas J, Polacco JC, Freyermutk SK, Sattelmacher B (1999). Significance of nickel for plant growth and metabolism. J. Plant. Nutr. Soil. Sci. 162:241-256.

Godzik B (1993). Heavy metal contents in plants from zinc dumps and reference area. Pollut. Bot. Stud. 5:113-132.

Greenway H, Munns R (1980). Mechanism of salt tolerance in nonhalophytes. Ann. Rev. Plant Physiol. 13:149-190.

Hewitt EJ (1966). Sand and water culture methods used in the study of plant nutrition. Second edition. Technical communication no. 22 (Revised). Comm. Wealth Agric. Bureaux, Farnham Royal, Bucks, England.

John R, Amhad P, Gadgil K, Sharma S (2009). Heavy metal toxicity: Effect on plant growth, biochemical parameters and metal accumulation by Brassica juncea L. Int. J. Plant Prod. 3(3):161-165.

Johnson MS, Eaton JW (1980). Environmental contamination through residual trace metal dispersal from a derelict lead-zinc mine. J. Environ. Qual. 9:175-179.

Jones LHP, Clement CR, Hooper MJ (1973). Lead uptake from solution by perennial ryegrass and its transport from roots to shoots. Plant Soil 38:403-414.

Mishra A, Choudhari MA (1998). Amelioration of lead and mercury effects on germination and rice seedling growth by antioxidants. Biol. Plant 41:469-473.

Nagajyoti PC, Dinakar N, Prasad TNVKV, Suresh C, Damodharam T (2008). Heavy metal toxicity : Industrial Effluent effect on Groundnut (Arachis hypogaea L.) Seedlings. J. Appl. Sci. Res. 4(1):110-121.

Ona LF, Alberto AM, Prudente JA, Sigua GC (2006). Levels of Pb in urban soils from selected cities in a contrail region of the Philippines. Environ. Sci. Pollut. Res. 13:177-183.

Panda SK, Khan MH (2003). Antioxidant efficiency in Oryza sativa leaves under heavy metal toxicity. J. Plant Biol. 30:23-29.

Pandey N, Pathak GC (2006). Nickel alters antioxidative defense and water status in green gram. Ind. J. Plant Physiol. 11:113-118.

Prasad DDK, Prasad ARK (1987). Altered a-amino luvelinic acid metabolism by $\mathrm{Pb}$ and $\mathrm{Hg}$ in germinating seedling of Bajra (Pennisetum typhoidenum). J. Plant Physiol. 127:241-249.

Saxe H (1991). Phytosynthesis and stomatal response to polluted air and the use of physiological and biochemical response easy detection 
and diagnostic tools. In: Gallow JA (ed.), Adv. Bot. Res. Acad. Press, Toronto, pp. 1-128.

Sinclain TR, Serraj R (1995). Dinitrogen fixation sensitivity to drought among grain legume species. Nature 378:344.

Singh SS, Khan NA, Rahat N, Anjum NA (2008). Photosynthetic traits and activities of antioxidant enzymes in blackgram (Vigna mungo L. Hepper). Under Cadmium stress. Am. J. Plant Physiol. 3:25-32.

Singh UP, Pandey VB, Singh KN, Singh RON (1973). Structural and biogenic relationships of isoflavonoids. Can. J. Bot. 166:1901-1910.

Somashekaraiah BV, Padmaja K, Prasad ARK (1992). Phytotoxicity of cadmium ions on germinating seedlings of mung bean (Phaseolus vulgaris) : Involvement of lipid peroxides in chlorophyll degradation. Physiol. Plant 85:85-89.
Stobart AK, Griffiths WT, Ameen-Bukhari I, Sherwood RP (1985). The effect of $\mathrm{Cd}^{+2}$ on the biosynthesis of chlorophyll in leaves of barley. Physiol. Plant 63:293-298.

Van Assche F, Clijster H (1990). Effects of metal on enzyme activity in plants. Plant Cell Environ. 13:195-206.

Verma S, Dubey RS (2003). Lead toxicity induces lipid peroxidation and alters the activities of antioxidant enzymes in growing rice plants. Plant Sci. 164:645-655. 